\title{
Income Smoothing Via Loan Loss Provisions and IFRS Implication: Evidence from Ethiopian Banks
}

\author{
Tesfamlak Mulatu Mune* \\ Department of Accounting and Finance, Injibara University, PO box 40, Injibara, Ethiopia \\ Abiy Getahun Kolech \\ Department of Accounting and Finance, Jimma University, PO box 378, Jimma, Ethiopia
}

\begin{abstract}
(Self-Sponsored information)
Abstract

text Using a single stage regression that models the non-discretionary part of loan loss provisions, we establish whether Ethiopian banks use loan loss provisions to smooth their income in a country with no foreign banks and high dominance of state ownership. Existing literature suggests that banks use loan loss provisions as a tool for income smoothing. Results support bank income smoothing via loan loss provisions and need of external fund have significant positive influence on loan loss provisioning towards income smoothing practice of Ethiopian banks in anticipation to attract external funds.
\end{abstract}

Keywords: Banks, Ethiopia, IFRS, Income Smoothing, Loan Loss Provisions.

DOI: $10.7176 / \mathrm{EJBM} / 11-16-06$

Publication date:June $30^{\text {th }} 2019$

\section{Introduction}

Banking industry is one of the most profitable industries in Ethiopia and witnessed unprecedented growth in terms of deposit mobilization and disbursement of credit. Generally, banks' largest assets are loan and advances where lending is the main activity to generate income, thus, they are considered as a risky business (Foos, et al. (2010)). Credit risk is the potential financial loss resulting from the failure of the borrower or counterparty to meet its obligation in accordance with agreed terms (Watanabe (2007)). Credit risk in banks play a central role as it could endanger bank solvency and stability, thus have substantial economic significance (Ahmed, Takeda, and Thomas (1999)). Therefore, to absorb any losses arising from loan default banks make a reserve for the future loan losses using loan loss provisions (LLP) (Hasan and Wall (2004), Wahlen (1994)). Loan loss provisions (LLP) can be defined as estimation for probable loan losses for the current year and this amount will be charged on the income statement as expense (non-cash) on a yearly basis (Walter (1991), Wahlen (1994)).

Loan loss provisions (LLP) are relatively large accrual of banks, set for the purpose adjusting banks' loan loss reserves to reflect expected future losses on their loan portfolios (Abdu, Shah, \& Mohd (2015)). Hence, in theory, the accrual of loan loss provisions (LLP) in the income statement of banks should be solely reflect credit risk. However, in practice, LLP is in many countries left to the judgment of banks' managers and as a result, they are one of the important items of the income statement subject to discretionary managerial decisions (Daniel, et al. (2006)). In this regard, by referring past theoretical and empirical evidence, Wall and Koch (2000) argue that banks have incentives for using their discretion in establishing LLP to manage reported earnings and capital. Yet, prior studies whether bank managers use their discretion over LLP to smooth earnings are not unanimous.

Earlier studies by Greenawalt and Sinkey (1988) and Ma (1988) indicate that bank managers use their discretion over LLP to smooth their reported earnings. Lately, also there are several supportive literatures which evidences the existence of a positive relation between LLP and earnings (before taxes and LLP) which is consistent with smoothing earnings via LLP (Bhat (1996), Collins, et al. (1995)). The same result has been revealed in recent studies (Dolar (2016), Leventis, et al. (2011), Onalo, et al. (2014)). However, there are studies with no evidence regarding to banks income smoothing using LLP (Ahmed, et al. (1999), Beatty, et al. (1995)).

Aforementioned and other studies have been conducted to assess the manipulation LLP to smooth bank earnings in different countries. Since the topic gained attention when the Securities and Exchange Commission (SEC) in US asked the loan loss accounting of SunTrust Banks, Inc. in the autumn of 1998, most of the research has been carried out on US bank sample. Relatively less numbers of studies have been carried out on data from other countries. This study makes an attempt to bridge this gap and tries to study the Ethiopian banks data with reference to income smoothing via LLP.

It is worth noting that the implementation of International Financial Reporting Standards (IFRS) had important implications regarding the use of LLP for income smoothing. Leventis, et al. (2011) show empirically that income smoothing through LLP was substantially reduced after IFRS implementation in the European sample, thus improving the quality of banks' financial reports. Based on this premises, little study was done that empirically investigate IFRS effect on Ethiopian banks income smoothing practice. Though, it is stated that banking sector in Ethiopia has started using IFRS voluntarily since 2003 (Alemi and Pasricha (2016)). 
This study therefore motivated because of the limited studies referring to Ethiopian banks in the area of income smoothing via LLP and IFRS implication. Moreover, the distinctive setting of banks in Ethiopia such as restriction of foreign ownership and high dominance of state owned banks may limit the possibility of inferring existing studies to Ethiopian banks. Hence, it is imperative to clarify whether bank managers manipulate LLP in order to smooth reported earnings and IFRS implication in the context of Ethiopian banks.

\section{Hypotheses}

Loan loss provisions (LLP) can have significant effects on the reported earnings, as they are a large accrual for banks. The main aim of manipulating this provision is to smooth income, as reducing earnings variability means reducing perceived risk, because variability in earnings is a key indicator of risk (Ahmed, Takeda, and Thomas (1999), Beatty, Chamberlain, and Magliolo (1995), Collins, Shackelford, and Wahlen (1995)). In other words, higher earnings variability means higher perceived risk and required risk premiums, which provides an incentive for bank managers to smooth income through loan loss provisions.

Empirical evidence from previous studies indicates that banks generally use loan loss provisions (LLP) to smooth earnings (Anandarajan, Hasan, and McCarthy (2007), Daniel, Vicente, and Jesús (2006), Greenawalt and Sinkey (1988)). Bank managers deliberately understated loan loss provisions to mitigate the adverse effect of other factors on earnings in the case of poor performance and overstated in the case of good performance in order to reduce the variability of earnings. Therefore, the existence of income smoothing through loan loss provisions is illustrated by a positive relationship between earnings (before taxes and loan loss provisions) and loan loss provisions. Thus, we hypothesize as:

H1: Loan loss provisions positively associated with earnings (before tax and loan loss provisions).

When more information on loan loss accounting and limited opportunistic discretion exist, it is expected that the incentives for discretionary use of loan loss provisions for income smoothing will be reduced (Ewert and Wagenhofer (2005), Daniel, Vicente, and Jesús (2006)). Principles-based standards called IFRS which require extensive disclosure, remove alternative accounting treatments and encourage more rigorous enforcement came to effect since 2005 (IASB (2016)). Based on this premises, no study was done that empirically investigate IFRS effect on Ethiopian banks income smoothing practice. Though, it is stated that banking sector in Ethiopia has started using IFRS voluntarily since 2003 (Alemi and Pasricha (2016)). Consistent with the objective of IASB, the finding by Leventis, et al. (2011) prevails the implementation of IFRS significantly reduced income smoothing activity of banks through loan loss provisions (LLP) in Europe. From this, we hypothesize as;

$\mathrm{H} 2$ : The relation between loan loss provisions and earnings (before tax and loan loss provision) will be negative for banks in the periods where IFRS is used to prepare financial reports relative to the non-IFRS using banks and periods.

The debt to equity ratio is often used to measure a company's degree of financial leverage (Meaza (2014)). The higher the degree of financial leverage, the more vulnerable a company is to volatile earnings reports and downturns in the economy due to the obligation to service the debt and incur interest expense (Hilliard (2013). Thus, the propensity to smooth earnings is high when debt to equity ratio tend to be high meaning income smoothing and debt to equity ratio are positively related. Since, the existence of income smoothing through loan loss provisions is illustrated by a positive relationship between loan loss provisions and earnings (before taxes and loan loss provisions). So, the hypothesis in this regard is as follows:

H3: There is a positive relationship between Debt to Equity ratio and the loan loss provision.

According to Zoubi and Al-Khazali (2007) and Fernando and Ekanayake (2015) bank managers' incentive to smooth income via loan loss provisions linked with their need of external fund. In order to attract external funds, the perceived risk will be adjusted by the loan loss provisions. The external fund need usually reflected by loan to deposit ratio, the higher the ratio, the more the need of external funds. A positive relationship between loan loss provisions and loans to deposit ratio will be expected because to attract external funds a bank must reduce the fluctuations of the earnings by increasing loan loss provisions if the earnings are high and decreasing loan loss provisions if the earnings are low. This leads us to the following hypothesis:

H4: There is a positive relationship between loans to deposit ratio and the loan loss provision.

\section{Empirical Strategy}

This study utilizes a balanced panel data set considering nine banks for the period 2005 to 2014. In this study from total of 19 banks in Ethiopia, we select nine banks as the sample on the basis of some criteria, literature widely use homogenous data in analyzing banking industry in the form of commercial banks only, hence exclude government development banks from the sample to report more meaningful results (Leventis, Dimitropoulos, and Anandarajan (2011)). Accordingly, the banks in the sample are solely commercial banks that consists state and private banks. In addition, to be included in the sample the bank should have at least 10 years data ranging from 2005 up to 2014. The sample constitutes banks using GAAP (non-IFRS) or IFRS to prepare their financial statements during entire study period and banks that have switched from using non-IFRS to IFRS. The banks 
financial information and macroeconomic data, such as Gross Domestic Product (GDP), are gathered from the National Bank of Ethiopian (NBE). The period of analysis is restricted to this period due to the availability of consistent information.

Following previous studies like Ahmed, et al. (1999), we employ loan loss provisions $\left(L L P_{i t}\right)$ as a dependent variable to test income smoothing practice. Though, usually accruals are disentangled into accruals over which management has discretion (which can be used to smooth earnings) and accruals over which management does not have discretion. Therefore often a two-stage analysis is chosen when researching income smoothing through the use of loan loss provisions, which separates the discretionary part of the accrual from the non-discretionary part in the first stage. In the first stage the non-discretionary part of loan loss provisions is modeled and the residual from this stage, which represents the discretionary part, is used in the second stage as the dependent variable.

However, this approach has a big disadvantage, namely that it systematically underestimates the absolute value of the regression coefficients in the second stage (Kanagaretnam, Lobo, and Yang (2005)). To counter this, following Kanagaretnam, et al. (2005) in this study we use a single-stage regression analysis. Additionally, to increase the reliability of the empirical results, Zenderski (2005) found that the use of one-stage estimations showed the same results as two-stage regressions. In single-stage, isolating the discretionary component of the loan loss provisions through variable control elements that were considered non-discretionary is common in literature. Hence, the study take in three control variables as indicators of the non-discretionary component of the provision accounts.

One control variable is the changes in total loan outstanding of bank $i$ at year t scaled by average total assets $\left(\right.$ CHLOAN $\left._{i t}\right)$ which measures default risk. Typically, the higher the loan growth, the higher probability of default would be. Therefore, it should have a positive relationship with loan loss provisions. However, as cited by Leventis, et al. (2011), the influence of this variable on loan loss provisions depends on the quality of incremental loans (Lobo and Yang (2001)).

Another control variable is ratio of beginning loan loss allowance to average total assets of bank $i$ at year $\mathrm{t}$ $\left(B L L A_{i t}\right)$. Besides controlling for default risk, this non-discretionary variable also captures prior provisions because the loan loss allowance account provides a summary of past decision regarding loan loss provisions, loan charge-offs, and charge-offs' recoveries. According to Wahlen (1994), a negative coefficient is expected for $\left(B L L A_{i t}\right)$. This is because this year's loan loss provisions are expected to be lower if in previous periods the managers use their discretion to overstate expected loan losses.

Other essential variable to measure bank risk is total loans divided by total assets of banki at year $\mathrm{t}$ $\left(L O A N T A_{i t}\right)$. This acts as a proxy for the credit risk of bank's loan portfolio, although Bouvatier and Lepetit (2008) emphasized that non-performing loans (NPL) perform better as an indicator of risk. However, the NPL data are not consistently available on data collected from NBE. Generally, the provisions amount is determined based on loan portfolio quality. The rise in the loan portfolio forces a bank to increase loan loss provisions due to higher default risk. Thus, the coefficient we expect is positive.

The main variable of interest is earnings before taxes and loan loss provisions of bank $i$ at year $t$ scaled by average total assets $\left(E B T P_{i t}\right)$. According to studies such as Ahmed, et al. (1999) and Leventis, et al. (2011), this variable used specifically to measure the evidence of income smoothing. A positive coefficient affirms income smoothing, where banks increase loan loss provisions when earnings (before taxes and loan loss provisions) rise. To examine the degree of leverage relation with loan loss provisions, we use the total debt to common equity ratio $\left(D E Q_{i t}\right)$. Whereas, to test the need of external funds, we employ the loan to deposit ratio of bank $i$ at year $\mathrm{t},\left(L O A D P O_{i t}\right)$.

To see the effect of IFRS adoption, we use a dummy variable to differentiate between adopters and nonadopters. In view of this, $I F R S D_{i t}$ denotes a dummy variable, equal to one for IFRS adopters' post-IFRS periods and zero for non-adopters and the pre-IFRS time of adopters. The interaction term of $E B I T P_{i t} \times I F R S D_{i t}$ also observes differences in income smoothing activities for banks and periods where IFRS used to prepare financial reports relative to non-IFRS using banks and periods. Similar to Daniel, et al. (2006) the study incorporate the natural logarithm of total assets of bank i year t $\left(L N T A_{i t}\right)$ to control for bank size. To control business cycle, we use real GDP per capita growth rate $\left(\mathrm{GDP}_{\mathrm{t}}\right)$.

Based on the above explanation, we develop a regression model in order to test whether Ethiopian banks use loan loss provisions (LLP) to smooth earnings and the level of IFRS relevance. For this reason, following Leventis, et al. (2011), we adapt a modified version of the model used by Ahmed, et al. (1999).

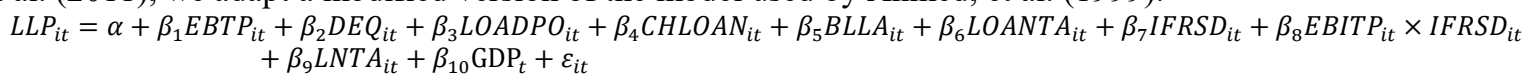


Table 3.1: Description of variables

\begin{tabular}{cll}
\hline Variable & Definition & Expected sign \\
\hline$L L P_{i t}$ & Loan loss provisions scaled by average total assets & N/A \\
$E B T P_{i t}$ & Earnings before taxes and LLP scaled by average total assets & + \\
$D E Q_{i t}$ & Total debts to total common equity ratio & + \\
$L O A D P O_{i t}$ & Total loans and advances divided to total deposits & + \\
$C H L O A N_{i t}$ & Changes in total loans and advances scaled by average total assets & + \\
$B L L A_{i t}$ & Beginning loan loss allowance scaled by average total assets & - \\
$L O A N T A_{i t}$ & Total loans and advances divided by total assets & + \\
$I F R S D_{i t}$ & Dummy variable equal to 1 for IFRS using periods of IFRS & N/A \\
& implemented banks and year, 0 otherwise & \\
$E B I T P_{i t}$ & Interaction term to capture the evidence of IFRS effect & - \\
$\times I F R S D_{i t}$ & & \\
$L N T A_{i t}$ & Natural logarithm of total assets & + \\
$\mathrm{GDP}_{t}$ & Real GDP per capita growth rate & - \\
\hline
\end{tabular}

\section{Results and Discussion}

Table 4.1: Fixed-Effect Regression Results

\begin{tabular}{|c|c|c|c|c|c|}
\hline Independent Variables & Expt. Sign & Coefficient $(\beta)$ & Robust Std. Err. & $t$ & $p>t$ \\
\hline Constant & N/A & $0.0108079 * *$ & 0.0044228 & 2.44 & 0.04 \\
\hline$E B T P_{i t}$ & + & $0.236955^{* *}$ & 0.0841967 & 2.81 & 0.023 \\
\hline$D E Q_{i t}$ & + & 0.0004903 & 0.0003055 & 1.6 & 0.147 \\
\hline$L O A D P O_{i t}$ & + & $0.0408955 * *$ & 0.0161016 & 2.54 & 0.035 \\
\hline CHLOAN $_{i t}$ & + & -0.011315 & 0.0080242 & -1.41 & 0.196 \\
\hline$B L L A_{i t}$ & - & -0.0008323 & 0.0021167 & -0.39 & 0.704 \\
\hline$L O A N T A_{i t}$ & + & -0.0454913 & 0.0214539 & -2.12 & 0.067 \\
\hline$I F R S D_{i t}$ & & -0.0038989 & 0.0048006 & -0.81 & 0.44 \\
\hline$E B I T P_{i t} \times I F R S D_{i t}$ & - & -0.0516631 & 0.1111327 & -0.46 & 0.654 \\
\hline$L N T A_{i t}$ & + & $-0.0022121 * * *$ & 0.0005177 & -4.27 & 0.003 \\
\hline $\mathrm{GDP}_{t}$ & - & -0.0004306 & 0.0003343 & -1.29 & 0.234 \\
\hline$F(10,71)=6.42$ & \multicolumn{2}{|c|}{ Prob $>F=0.0000$} & \multicolumn{3}{|c|}{ Adj. $R-s q:=.34184712$} \\
\hline $\mathrm{N}=90$ & \multicolumn{2}{|c|}{ Banks $=9$} & \multicolumn{3}{|c|}{ Obs. Year $2005-2014$} \\
\hline
\end{tabular}

We perform the Hausman's specification test to detect which panel regression model should be used in order to give a more consistent and efficient result. Since the output demonstrates p-values of 0.0112 which is less than the significance level 0.05 we reject $H o$ (random effect model), thus we run fixed effect regression model. In order to see if data present any specification problem we test heteroscedasticity, serial autocorrelation and spatial autocorrelation. The results indicates that, the data does not have first-order autocorrelation but it has heteroscedasticity and spatial autocorrelation problem.

Table 4.1 reports the Fixed-Effect panel least squares results of our model obtained by regressing loan loss provision $\left(L L P_{i t}\right)$ on independent variables. To control the presence of heteroscedasticity and autocorrelations the standard errors of estimators are made to be robust clustered by banks. The model is significant at $F(10,71)=$ 6.42 , $p$-value $<0.01$, indicating that, the entire model is well fitted and good enough in explaining the variation on the dependent variable. The value of adjusted $\mathrm{R}^{\wedge} 2$ is 0.3418 , which indicate that the explanatory variables in this study can account for $34.2 \%$ of the variation in loan loss provisions. Therefore, the remaining $65.8 \%$ of the variation in loan loss provisions are caused by other factors that are not included in this model. Because, bank managers have incentives to use loan loss provisions to manage earnings and regulatory capital as well as to communicate or 'signal' private information about future prospects (Ahmed, Takeda, and Thomas (1999)). However, this study focuses on loan loss provisions as a tool for income smoothing and not as a tool for capital management or signaling future oriented information.

As we observe Table 4.1, the coefficient $(\beta=0.236955, \mathrm{t}=2.81, \mathrm{p}<0.05)$ for variable of our interest, ratio of earnings before taxes and loan loss provisions to average total assets $\left(E B T P_{i t}\right)$ is positive and statistically significant. It shows that on average, an increase in earnings before taxes and loan loss provisions by one percent influences loan loss provisions (LLP) in positive direction by $23.7 \%$, citrus paribus. This indicates that on average, banks in the sample do smooth reported earnings using loan loss provisions over the entire period of analysis.

Our finding generally consistent with Dolar (2016), Greenawalt and Sinkey Jr (1988), and Rivard, et al. (2003) for the US market and Curcio and Hasan (2008) and Duru and Alexandros (2013) for European sample. The result 
also supports the findings by Zoubi and Al-Khazali (2007) and Daniel, et al. (2006) for the GCC region and Spanish banking industry respectively. According to Fonseca and Gonza'lez (2008) who conducted the study on the determinants of income smoothing by management of loan loss provisions in banks around the world, a lower income smoothing in developed countries than developing countries. Thus, our study result confirms their findings.

In literature, income smoothing leads to lower accounting transparency and deteriorates financial reporting quality of firms (Iatridis (2010)). In the sense that such accounting information seems less effective in facilitating the ability of outside investors and regulators to monitor and discipline banks. Therefore, poor financial reporting quality and less transparency in Ethiopian banks included in the sample for the study period can be possible explanation for our empirical evidence. This is likely due to loopholes of certain rules and regulations of traditional bank regulatory practices requiring limited disclosure on loan loss accounting.

The coefficient for debt to equity ratio $\left(D E Q_{i t}\right)$ is not statistically significant, thus we have no evidence to say debt to equity $\left(D E Q_{i t}\right)$ has influence on determination of loan loss provisions. This result supports the study on determinants of loan loss provisions in Malaysia by Mohd Isa, et al. (2013) who found the debt to equity ratio has no significantly determine the loan loss provisions in Malaysia.

A significant positive coefficient $(\beta=0.0408955, \mathrm{t}=2.54)$ on loan to deposit $\operatorname{ratio}\left(L O A D P O_{i t}\right)$, indicates that when on average an increase in loan to deposit ratio by one percent influences loan loss provisions in positive direction by $4.09 \%$, other things remain unchanged. This result implies that bank managers tend smooth earnings through loan loss provisions in order to attract external funds. Our findings are consistent with Fernando and Ekanayake (2015) whose study show that the extent of income smoothing through loan loss provisions is positively related to the ratio of loans to deposits. As the growing industry in Ethiopia, banks effort to capture the market is evident by lending most of their deposits to the customers as loans and advances. Pinho (1997) found that provision for loan losses would be greatly affected by the banks intention to capture high market share from loans and advances.

Regarding to the non-discretionary component of loan loss provisions (LLP), the coefficients of the variables changes in total loans and advances scaled by average total assets $\left(C H L O A N_{i t}\right)$, beginning loan loss allowances scaled by average total assets $\left(B L L A_{i t}\right)$, and total loans and advances divided by total assets $\left(L O A N T A_{i t}\right)$ are not statistically significant.

The coefficient of dummy variable for implementing periods of IFRS adopted banks during the study period $\left(I F R S D_{i t}\right)$ and the interaction variable $\left(E B I T P_{i t} \times I F R S D_{i t}\right)$ turn out to be not significant. This shows we are not in the position to say there is difference in loan loss provisioning and income smoothing for observations with IFRS implementation and non-IFRS (GAAP). As a result, our second hypothesis is not supported, contradicting to the findings of Leventis, et al. (2011) and Onalo, et al. (2014), that IFRS adoption is associated with lower earnings management via loan loss provisions to European banks, and Malaysian and Nigerian banks, respectively. According to Ball, et al. (2003), the accounting quality is largely a determinate of firms' reporting incentives created by market forces and institutional factors rather than by accounting standards. In addition, strong enforcement mechanisms are associated with lower earnings manipulation and higher disclosure quality (Elerle and Schleicher (2013)). Hence, IFRS themselves may not merely mean material changes in income smoothing and reporting quality.

With respect to the control variables, bank size measured by natural logarithm of total assets $\left(L N T A_{i t}\right)$ seem to negatively affect the level of loan loss provisions. This evidences that on average relatively smaller banks maintain higher levels of loan loss provisions. According to Leventis, et al. (2011), this may be attributed to less efficient strategies to credit risk diversification of small banks and/or presumably large banks might consider that their loans are not risky, or alternatively, may be lowering loan loss provisions to inflate earnings. Annual real GDP growth $\left(\mathrm{GDP}_{\mathrm{t}}\right)$, a variable controlling macro-economic factors is happened to be insignificant. This result suggests that that the macro-economic condition does not explain the way average banks in the sample determine their loan loss provisions.

As already mentioned, Ethiopian banking industry is dominated by state owned bank in terms of size and market share. State ownership combined with largeness of those banks, may make more politically visible and subject to regulation. Thus, politically visible firms have incentives to report smooth profits by exercising discretion over loan loss provisions to avoid the scrutiny of regulators (Chen and Tseng (2012)). In addition, Fernando and Ekanayake (2015) suggest that it is important to account for the extent of state ownership of banks. Therefore, for sensitivity reason we run fixed effect regression model excluding two state owned banks but there is no significant differences from the main result of the study.

\section{Conclusions}

We investigate the use of loan loss provisions (LLP) to smooth income by Ethiopian banks using panel data fixed effect regression model. The empirical results of this study demonstrates that indeed Ethiopian banks included in the sample engage in income smoothing activities via loan loss provisions in the periods studied. The study results furthermore suggests bank managers tend smooth earnings in order to attract external funds. It is reasonably 
possible to state that, this is because of banks effort to capture the unpenetrated market by lending most of their deposits to the customers as loans and advances. Income smoothing as common form of earnings management would likely to reduce the quality of financial statement information because the data presented might not disclose the real condition of the firms (Iatridis (2010)). Therefore, this study encourages the policy makers to rethink the loopholes of their policies because earnings can be managed using the loopholes of certain rules and regulations. In addition, higher loan loss accounting disclosure requirements by IFRS will lead to lower levels of income smoothing. However, IFRS needs strong enforcement mechanisms; therefore, we suggest that the Accounting and Auditing Board of Ethiopia (AABE) which is in charge of regulating and guiding the overall financial reporting practices of the country should cooperate with National bank of Ethiopia (NBE) which regulate the banking sector of Ethiopia to enforce the use of IFRS to improve the accounting quality of banks. Furthermore, shareholders must exert appropriate monitoring on managers action and to implement suitable control devices to minimize possible agency conflicts.

\section{References}

Ahmed, A. S., Takeda, C., \& Thomas, S. (1999). Bank loan loss provisions: a reexamination of capital management, earnings management and signaling effects. Journal of Accounting and Economics, 28, 1-25.

Alemi, T. D., \& Pasricha, J. S. (2016). IFRS Adoption Progress in Ethiopia. Research Journal of Finance and Accounting, 7(1), 69-81.

Anandarajan, A., Hasan, I., \& McCarthy, C. (2007). Use of loan loss provisions for capital, earnings management and signaling by Australian banks. Journal of Accounting and Finance, 47, 357-379.

Ball, R., Robin, A., \& Wu, J. S. (2003). Incentives versus standards: properties of accounting income in four East Asian countries. Journal of Accounting and Economics, 36(1-3), 235-270.

Beatty, A., Chamberlain, S., \& Magliolo, J. (1995). Managing financial reports of commercial banks: the influence of taxes, regulatory capital and earnings. Journal of Accounting Research, 33(2), 231-262.

Bhat, V. (1996). Banks and income smoothing: an empirical analysis. Applied Financial Economics, 505-510.

Bouvatier, V., \& Lepetit, L. (2008). Banks' Procyclical behavior: Does provisioning matter? International Financial Markets, Institutions and Money, 18, 513-526.

Chang, R., Shen, W., \& Fang, C. (2008). Discretionary Loan Loss Provisions and Earnings Management for the Banking Industry. International Business \& Economics Research Journal, 7(3), 9-20.

Chen, P., \& Daley, L. (1996). Regulatory capital, tax, and earnings management effects on loan loss accruals in the Canadian banking industry. Contemporary Accounting Research, 13(1), 91-128.

Chen, W., \& Tseng, H.-H. (2012). Evidence of Income Smoothing from Securitized Loans and Loan Loss Provisions: Real Transactions vs. Accruals. The International Journal of Accounting Studies, 54(1), 43-75.

Collins, J., Shackelford, D., \& Wahlen, J. (1995). Bank differences in the coordination of regulatory capital, earnings and taxes. Journal of Accounting Research, 33, 263-292.

Curcio, D., \& Hasan, I. (2008). Earnings- and Capital-Management and Signaling: The Use of Loan-Loss Provisions by European Banks. Milan.

Daniel, P., Vicente, S.-F., \& Jesús, S. (2006). Earnings and Capital Management in Alternative Loan Loss Provision Regulatory Regimes. Documentos de Trabajo. Madrid: Banco de España.

Dolar, B. (2016). Income Smoothing Practices of US Banks Around the 2008 Financial Crisis. International Journal of Business Research, 10(1), 1-11.

Duru, K., \& Alexandros, T. (2013). An Empirical Examination of the Income Smoothing in the Nordic Banking Industry. Uppsala: University of Uppsala.

Elerle, B., \& Schleicher, M. (2013). Enforcement and Managers' Financial Reporting Behavior: A Review of the Empirical Enforcement Literature. Behavior Accounting.

Ewert, R., \& Wagenhofer, A. (2005). Economic effects of tightening accounting standards to restrict earnings management. Journal of Accounting Review, 43, 1101-1124.

Fernando, W. D., \& Ekanayake, E. M. (2015). Do Commercial Banks Use Loan Loss Provisions to Smooth Their Income? Empirical Evidence from Sri Lankan Commercial Banks. Journal of Finance and Bank Management, $3(1), 167-179$.

Fonseca, A. R., \& Gonza'lez, F. (2008). Cross-country determinants of bank income smoothing by managing loanloss provisions. Journal of Banking \& Finance, 32, 217-228.

Fudenberg, D., \& Tirole, J. (1995). A theory of income and dividend smoothing based on incumbency rents. Journal of Political Economy, 103(1), 75-93.

Greenawalt, M. B., \& Sinkey, J. F. (1988). Bank loan-loss provisions and the income-smoothing hypothesis: An empirical analysis, 1976-1984. Journal of Financial Services Research, 1(4), 301-318.

Hilliard, T. (2013). The Effects of Adopting IFRS: The Canadian Experience. Georgia: Georgia State University. IASB. (2016). Who we are and what we do. London: IFRS Foundation.

Iatridis, G. (2010). International Financial Reporting Standards and the Quality of Financial Statement Information. 
International Review of Financial Analysis, 19, 193-204.

Ismail, A., Shaharudin, R., \& Samudhram, A. (2005). Do Malaysian Banks Manage Earnings Through Loan Loss Provisions? Journal of Financial Reporting and Accounting, 3(1), 41- 47.

Kanagaretnam, K., Lobo, G. J., \& Yang, D. H. (2005). Determinants of Signaling by Banks through Loan Loss Provisions. Journal of Business Research, 58, 312-320.

Leventis, S., Dimitropoulos, E. P., \& Anandarajan, A. (2011). Loan Loss Provisions, Earnings Management and Capital Management under IFRS: The Case of EU Commercial Banks. Journal Financial Service Research, 40, 103-122.

Lobo, G. J., \& Yang, D. H. (2001). Bank managers' heterogeneous decisions on discretionary loan loss provisions. Review of Quantitative Finance and Accounting, 16, 223-250.

Ma, K. C. (1988). Loan loss reserve and income smoothing: The experience in the U.S. banking industry. Journal of Business Finance and Accounting, 15(4), 487-497.

Meaza, M. G. (2014). Determinants of insurance companies' profitability in Ethiopia. Addis Ababa: Addis Ababa University.

Mohd Isa, M. Y., Choong, Y. V., Gun Fie, D. Y., Mohamed, Z., \& Syed Agil, S. O. (2013). Asian Banking Implications from Crisis: Malaysian Commercial Banks' Income Smoothing Behaviour through Loan Loss Provisions. Journal of Business and Economics, 4(10), 1038-1050.

Mulford, C. W., \& Comiskey, E. E. (2002). The financial numbers game: detecting creative accounting practices. New York: Wiley.

Onalo, U., Lizam, M., Kaseri, A., \& Innocent, O. (2014). The Effect of Changes in Accounting Standards on Loan Loss Provisions (LLP) as Earnings Management Device: Evidence from Malaysia and Nigeria Banks (Part I). European Journal of Business and Social Sciences, 3(8), 231-242.

Pinho, P. S. (1997). An empirical analysis of the determinants of provisions for loan losses in Portugueses banks. Working Paper.

Rivard, R., Bland, E., \& Morris, G. (2003). Income smoothing behavior of U.S. banks under revised international capital requirements. International Advances in Economic Research, 9(14), 288-296.

Scott, W. R. (2003). Financial Accounting Theory (3rd ed.). Toronto: Prentice Hall.

Taktak, N., Zouari, S., \& Boudriga, A. (2010). Do Islamic banks use loan loss provisions to smooth their results? Journal of Islamic Accounting and Business Research, 1(2), 114-127.

Wahlen, M. J. (1994). The nature of information in commercial bank loan loss disclosures. The Accounting Review, 73-89.

Wall, D., \& Koch, W. (2000). Bank loan-loss accounting: a review of theoretical and empirical evidence. Georgia: Federal Reserve Bank of Atlanta.

Walter, A. (1991). Loan loss reseves. Economic Review, 20-30.

Zoubi, T. A., \& Al-Khazali, O. (2007). Empirical testing of the loss provisions of banks in the GCC region. Managerial Finance, 33(7), 50-.

\section{Appendix}

Annex (A) Banks Included in the Sample

\begin{tabular}{|l|l|c|c|}
\hline No. & \multicolumn{1}{|c|}{ Bank } & Year of Establishment & Remark \\
\hline 1. & Awash International Bank (AIB) & 1994 & GAAP \\
\hline 2. & Bank of Abyssinia (BOA) & 1996 & GAAP \\
\hline 3. & Commercial Bank of Ethiopia (CBE) & 1963 & IFRS (2003) \\
\hline 4. & Construction and Business Bank (CBB) & 2006 & IFRS (2003) \\
\hline 5. & Cooperative Bank of Oromia (CBO) & 2004 & IFRS (2013) \\
\hline 6. & Dashen Bank (DB) & 1995 & GAAP \\
\hline 7. & Nib International Bank (NIB) & 1999 & IFRS (2005) \\
\hline 8. & United Bank (UB) & 1998 & IFRS (2009) \\
\hline 9. & Wegagen Bank (WB) & 1997 & \\
\hline
\end{tabular}


Annex (B) Stata Output for Descriptive Statistics

- summarize LLP EBTP DEQ LOADPO CHLOAN BLLA LOANTA IFRSD LNTA GDP

\begin{tabular}{r|rrrrr} 
Variable & Obs & Mean & Std. Dev. & Min & Max \\
\hline LLP & 90 & .003786 & .0060161 & -.001031 & .037248 \\
EBTP & 90 & .0448249 & .0150575 & -.018074 & .073793 \\
DEQ & 90 & 8.371027 & 4.156924 & .151786 & 22.8041 \\
LOADPO & 90 & .6547975 & .1924666 & .2 & 1.29592 \\
CHLOAN & 90 & .1128107 & .1044486 & -.050718 & .70255 \\
\hline BLLA & 90 & .2049688 & .5406038 & 0 & 2.36925 \\
LOANTA & 90 & .4839127 & .1297354 & .023256 & .727676 \\
IFRSD & 90 & .4222222 & .4966806 & 0 & 1 \\
LNTA & 90 & 8.720197 & 1.30053 & 4.859812 & 12.40004 \\
GDP & 90 & 7.228 & 1.684027 & 4.47 & 9.69
\end{tabular}

Annex (C) Stata Output for Pairwise Correlation

- pwcorr LlP EBTP DEO LOADPO CHLOAN BLlA LOANTA LNTA GDP, atar(5)

\begin{tabular}{|c|c|c|c|c|c|c|c|}
\hline & LLP & EBTP & $\mathrm{DEQ}$ & LOADPO & CHLOAN & BLIA & LOANTA \\
\hline LLP & 1.0000 & & & & & & \\
\hline EBTP & $0.2514 *$ & 1.0000 & & & & & \\
\hline $\mathrm{DE} Q$ & -0.0629 & 0.0249 & 1.0000 & & & & \\
\hline LOADPO & $0.5265 *$ & 0.1639 & $-0.3130 *$ & 1.0000 & & & \\
\hline CHLOAN & $0.2093^{*}$ & -0.1698 & $-0.2368 *$ & $0.6036 *$ & 1.0000 & & \\
\hline BLLA & -0.0912 & 0.1034 & -0.0801 & -0.0635 & -0.0238 & 1.0000 & \\
\hline LOANTA & $0.4059 *$ & $0.3408 *$ & $-0.2536 *$ & $0.8660 *$ & $0.4917 *$ & 0.0204 & 1.0000 \\
\hline \multirow{3}{*}{$\begin{array}{l}\text { LNTA } \\
\text { GDP }\end{array}$} & $-0.3019 *$ & $0.2620 *$ & $0.6356 *$ & $-0.5456 *$ & $-0.4255 *$ & 0.0730 & $-0.4295 *$ \\
\hline & 0.1110 & 0.0124 & 0.0297 & 0.1200 & 0.1103 & -0.0350 & 0.1320 \\
\hline & LNTA & $G D P$ & & & & & \\
\hline $\begin{array}{r}\text { INTA } \\
\text { GDP }\end{array}$ & $\begin{array}{c}1.0000 \\
-0.3296 *\end{array}$ & 1.0000 & & & & & \\
\hline
\end{tabular}

Annex (D) Stata Output for Multicollinearty Test of VIF

\begin{tabular}{r|rr} 
\\
Variable & VIF & $1 /$ VIF \\
\hline LOADPO & 5.53 & 0.180769 \\
LOANTA & 4.93 & 0.202798 \\
LNTA & 3.74 & 0.267483 \\
DEQ & 2.14 & 0.466637 \\
EBTP & 1.86 & 0.538306 \\
CHLOAN & 1.81 & 0.552689 \\
GDP & 1.36 & 0.735777 \\
BLLA & 1.06 & 0.944433 \\
\hline Mean VIF & 2.80 &
\end{tabular}

vif

\begin{tabular}{r|rr} 
Variable & VIF & $1 / \mathrm{VIF}$ \\
\hline EBTPIFRSD & 17.36 & 0.057614 \\
IFRSD & 16.37 & 0.061074 \\
LOANTA & 6.50 & 0.153856 \\
LOADPO & 6.20 & 0.161273 \\
LNTA & 3.83 & 0.261142 \\
EBTP & 3.40 & 0.294283 \\
DEQ & 2.31 & 0.433475 \\
CHLOAN & 2.00 & 0.500416 \\
GDP & 1.37 & 0.728401 \\
BLLA & 1.16 & 0.865526 \\
\hline Mean VIF & 6.05 &
\end{tabular}




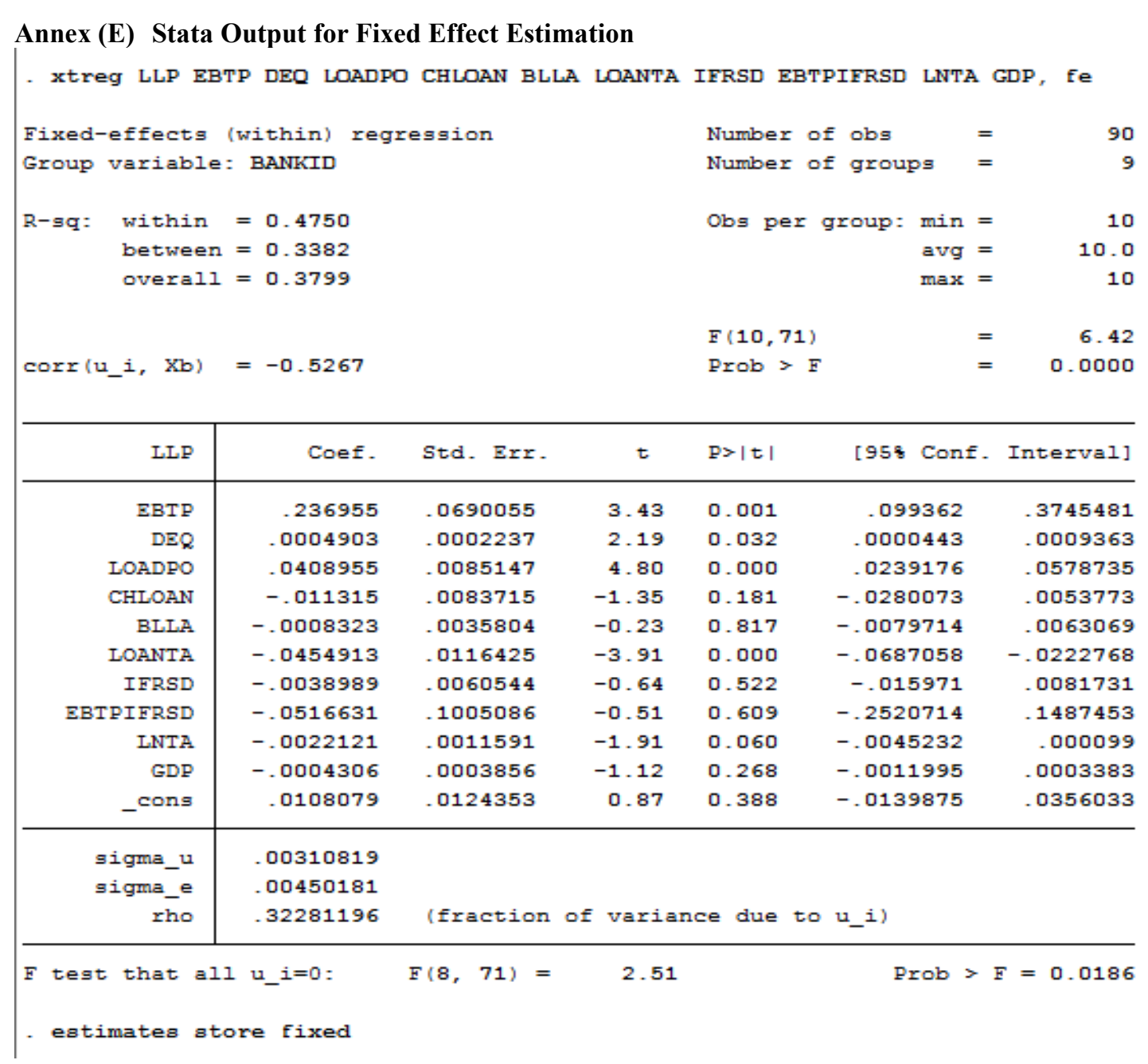




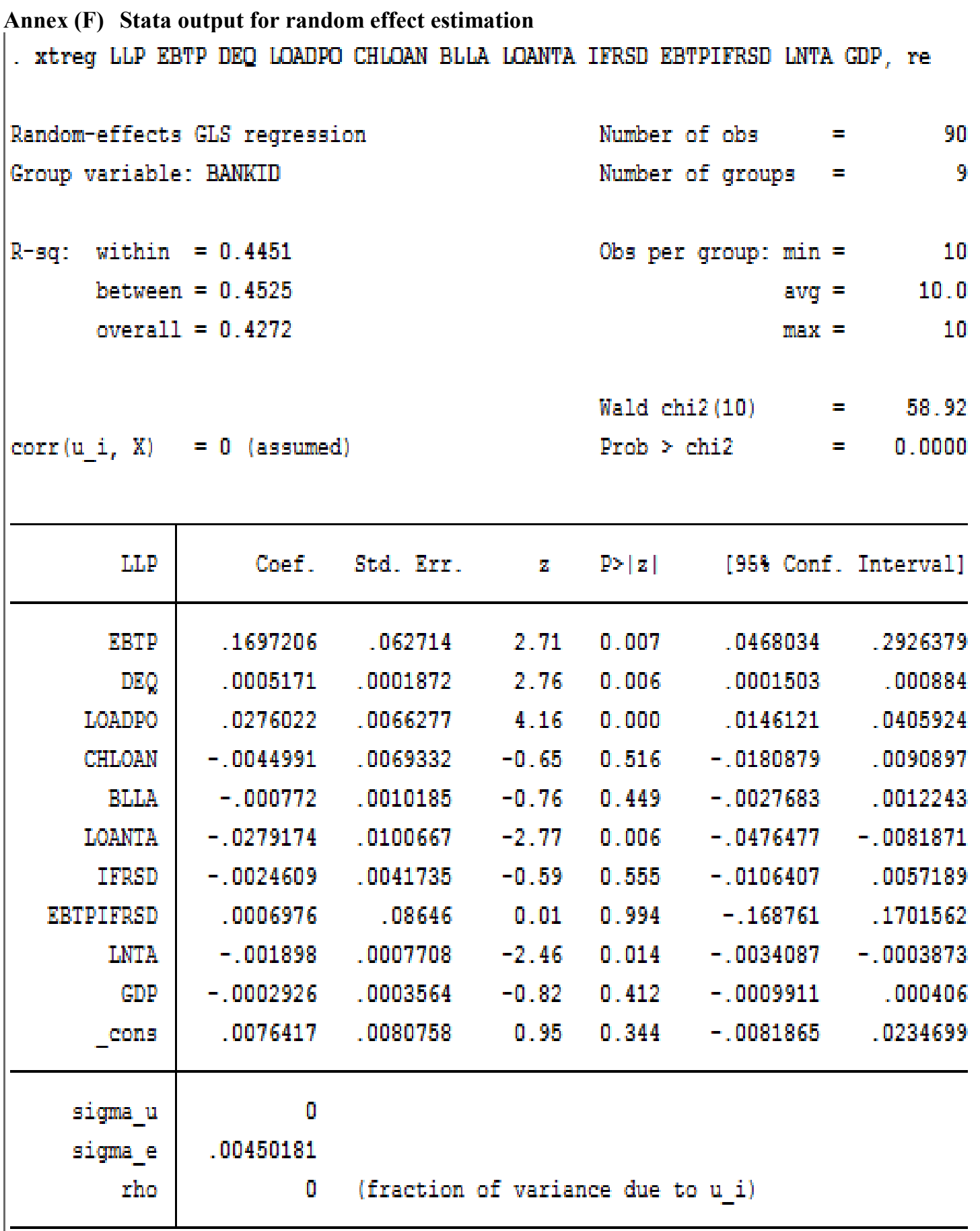

estimates store random 
Annex (G) Stata output for Hausman test

hausman fixed.

\begin{tabular}{|c|c|c|c|c|}
\hline & \multicolumn{2}{|c|}{ - Coefficients -} & \multirow{3}{*}{$\begin{array}{c}\text { (b-B) } \\
\text { Difference }\end{array}$} & \multirow{3}{*}{$\begin{array}{c}\operatorname{sqrt}\left(\operatorname{diag}_{\left(\mathrm{V}_{-}{ }^{\mathrm{b}}-\mathrm{V}_{-}{ }^{B}\right)}\right) \\
\text { S.E. }\end{array}$} \\
\hline & (b) & (B) & & \\
\hline & fixed & random & & \\
\hline EBTP & .236955 & .1697206 & .0672344 & .0287873 \\
\hline $\mathrm{DEQ}$ & .0004903 & .0005171 & -.0000269 & .0001225 \\
\hline LOADPO & .0408955 & .0276022 & .0132933 & .0053455 \\
\hline CHLOAN & -.011315 & -.0044991 & -.0068159 & .0046918 \\
\hline BLLA & -.0008323 & -.000772 & -.0000603 & .0034325 \\
\hline LOANTA & -.0454913 & -.0279174 & -.0175739 & .005849 \\
\hline IFRSD & -.0038989 & -.0024609 & -.001438 & .0043861 \\
\hline EBTPIFRSD & -.0516631 & .0006976 & -.0523606 & .0512507 \\
\hline LNTA & -.0022121 & -.001898 & -.0003141 & .0008656 \\
\hline GDP & -.0004306 & -.0002926 & -.0001381 & .0001472 \\
\hline
\end{tabular}

$\mathrm{b}=$ consistent under Ho and $\mathrm{Ha}$; obtained from xtreg

$B=$ inconsistent under $\mathrm{Ha}$, efficient under Ho; obtained from xtreg

Test: Ho: difference in coefficients not systematic

$$
\begin{array}{rlrl}
\operatorname{chi2}(10) & = & (b-B) & {\left[\left(V_{-} b-V_{-} B\right) \sim(-1)\right](b-B)} \\
& = & & 22.88 \\
\text { Prob }>\text { chi2 } & = & & 0.0112 \\
\text { (V_b-V_B is not positive definite) }
\end{array}
$$

Annex (H) Stata output for Heteroscedasticity test - xttest3

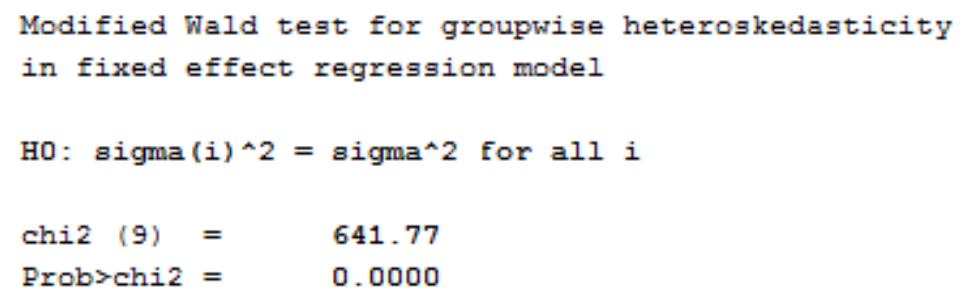

Annex (I) Stata output for serial correlation test . xtgerial LLP EBTP DEQ LOADPO CHLOAN BLLA LOANTA IFRSD EBTPIFRSD LNTA GDP

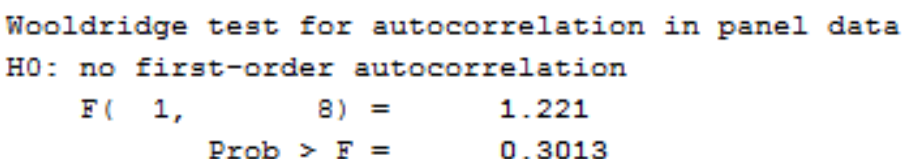

Annex (J) Stata output for spatial correlation test . xtcsd, pesaran abs

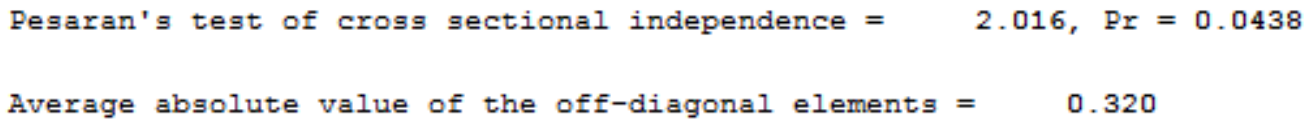


Annex (K) Stata output for fixed effect estimation (Robust Standard Errors)

. xtreg LLP EBTP DEQ LOADPO CHLOAN BLLA LOANTA IFRSD EBTPIFRSD LNTA GDP, fe vce (cluster BANKID)

Fixed-effects (within) regression

Group variable: BANKID

R-sq: within $=0.4750$

between $=0.3382$

overall $=0.3799$

$\operatorname{corr}\left(u_{-} i_{,} \mathrm{Xb}\right)=-0.5267$

$\begin{aligned} \text { Number of obs } & = \\ \text { Number of groups } & \\ \text { Obs per group: } \min = & 90 \\ \text { avg } & = \\ \max & =10.0\end{aligned}$

$F(8,8)$

Prob > F

(Std. Err. adjusted for 9 clusters in BANKID)

\begin{tabular}{|c|c|c|c|c|c|c|}
\hline \multirow[b]{2}{*}{ LLP } & \multicolumn{3}{|c|}{ Robust } & \multirow[b]{2}{*}{$p>|t|$} & \multirow[b]{2}{*}{ [958 Conf. } & \multirow[b]{2}{*}{ Interval] } \\
\hline & Coef. & Std. Err. & $\mathrm{t}$ & & & \\
\hline BBTP & .236955 & .0841967 & 2.81 & 0.023 & .0427971 & .431113 \\
\hline $\mathrm{DEQ}$ & .0004903 & .0003055 & 1.60 & 0.147 & -.0002142 & .0011948 \\
\hline LOADPO & .0408955 & .0161016 & 2.54 & 0.035 & .0037651 & .078026 \\
\hline CHLOAN & -.011315 & .0080242 & -1.41 & 0.196 & -.0298189 & .0071888 \\
\hline BLLA & -.0008323 & .0021167 & -0.39 & 0.704 & -.0057134 & .0040489 \\
\hline LOANTA & -.0454913 & .0214539 & -2.12 & 0.067 & -.0949642 & .0039816 \\
\hline IFRSD & -.0038989 & .0048006 & -0.81 & 0.440 & -.014969 & .0071712 \\
\hline BBTPIFRSD & -.0516631 & .1111327 & -0.46 & 0.654 & -.3079354 & .2046093 \\
\hline LNTA & -.0022121 & .0005177 & -4.27 & 0.003 & -.003406 & -.0010183 \\
\hline GDP & -.0004306 & .0003343 & -1.29 & 0.234 & -.0012016 & .0003403 \\
\hline _cons & .0108079 & .0044228 & 2.44 & 0.040 & .0006088 & .021007 \\
\hline sigma_u & .00310819 & & & & & \\
\hline sigma_e & .00450181 & & & & & \\
\hline rho & .32281196 & (fraction & vari & ce due & u_i) & \\
\hline
\end{tabular}


Annex (L) Stata output for fixed effect estimation (excluding stated owned banks) xtreg LLP EBTP DEQ LOADPO CHLOAN BLLA LOANTA IFRSD EBTPIFRSD LNTA GDP in 21/90, fe

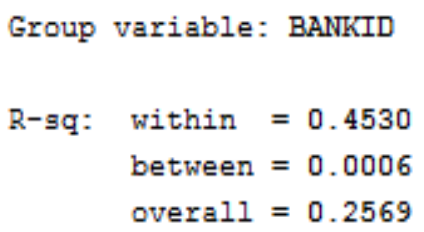

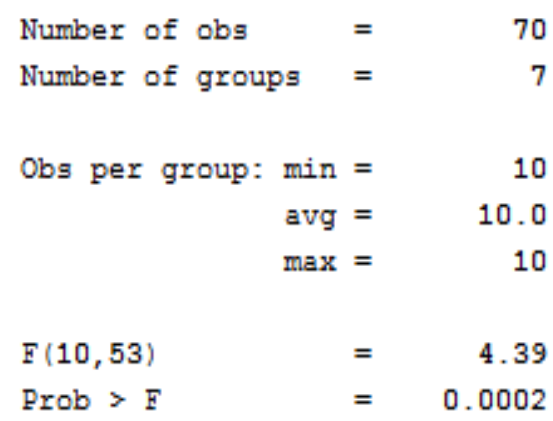

\begin{tabular}{|c|c|c|c|c|c|c|}
\hline LLP & Coef. & Std. Err. & $\mathrm{t}$ & $P>|t|$ & [95\& Conf. & Interval] \\
\hline EBTP & .20205 & .0725551 & 2.78 & 0.007 & .0565229 & .347577 \\
\hline DEQ & .0015199 & .0004752 & 3.20 & 0.002 & .0005669 & .0024729 \\
\hline LOADPO & .0446378 & .0104129 & 4.29 & 0.000 & .0237522 & .0655234 \\
\hline CHLOAN & -.0082243 & .0102919 & -0.80 & 0.428 & -.0288673 & .0124186 \\
\hline BLLA & .000364 & .0036285 & 0.10 & 0.920 & -.0069138 & .0076418 \\
\hline LOANTA & -.0558441 & .0135948 & -4.11 & 0.000 & -.0831119 & -.0285763 \\
\hline IFRSD & -.0076261 & .0088133 & -0.87 & 0.391 & -.0253033 & .0100511 \\
\hline BBTPIFRSD & .0236767 & .1445129 & 0.16 & 0.870 & -.2661794 & .3135328 \\
\hline LNTA & -.0030402 & .0013583 & -2.24 & 0.029 & -.0057646 & -.0003157 \\
\hline GDP & -.0009105 & .0004625 & -1.97 & 0.054 & -.0018382 & .0000172 \\
\hline -cons $^{\operatorname{con}}$ & .0173883 & .0136909 & 1.27 & 0.210 & -.0100721 & .0448487 \\
\hline sigma_u & .00350664 & & & & & \\
\hline sigma_e & .00437952 & & & & & \\
\hline rho & .39065486 & \multicolumn{5}{|c|}{ (fraction of variance due to $u_{-} i$ ) } \\
\hline
\end{tabular}

